\title{
PENGGUNAAN ZEOLIT UNTUK STABILISASI FORMULA EKSTRAK KULIT BUAH DELIMA SEBAGAI ANTIBAKTERI
}

\author{
Fitri Amalia ${ }^{1}$ dan Yustinus Purwamargapratala ${ }^{2}$ \\ ${ }^{1}$ Balai Pengujian Mutu Produk Peternakan, Kementerian Pertanian \\ Tanah Sereal, Bogor, Jawa Barat 16162 \\ ${ }^{2}$ Pusat Teknologi Bahan Industri Nuklir (PTBIN) - BATAN \\ Kawasan PUSPIPTEK, Serpong, Tangerang 15310 \\ Email: fitrirarakayla@yahoo.com
}

Received: 6 Februari 2017; revised: 22 Februari 2017; accepted: 3 April 2017

\begin{abstract}
ABSTRAK
PENGGUNAAN ZEOLIT UNTUK STABILISASI FORMULA EKSTRAK KULIT BUAH DELIMA SEBAGAI ANTIBAKTERI. Telah dilakukan penelitian penggunaan zeolit untuk stabilisasi formula ekstrak antibakteri. Ekstrak antibakteri yang digunakan diperoleh dari ekstraksi kulit buah delima dengan etanol. Ekstrak antibakteri dicampur dengan zeolit selama 24 jam pada kecepatan $150 \mathrm{rpm}$ dan suhu $27{ }^{\circ} \mathrm{C}$ selanjutnya dipanaskan pada suhu $38^{\circ} \mathrm{C}$ selama 24 jam. Hasil pengamatan menunjukkan bahwa zeolit mampu menjaga stabilitas aktivitas antibakteri formula ekstrak. Pada pengamatan pertumbuhan bakteri Bacillus cereus selama 24 jam, gabungan formula ekstrak-zeolit yang telah dipanaskan mampu menghambat pertumbuhan bakteri pada jam ke dua sampai pada titik nol. Jika dibandingkan dengan formula ekstrak tanpa zeolit pada kondisi yang sama, tidak mampu menghambat pertumbuhan bakteri sampai dengan titik nol kurva pertumbuhan bakteri. Jumlah bakteri bertambah dari $10^{6}$ sampai hampir mencapai $10^{9}$ koloni bakteri. Kondisi ini menunjukkan gabungan ekstrakzeolit mampu mempertahankan aktivitas antibakteri dari formula ekstrak terhadap pemanasan pada suhu $38^{\circ} \mathrm{C}$ selama 24 jam.
\end{abstract}

Kata kunci: Zeolit alam, Ekstrak kulit buah delima, Aktivitas antibakteri

ABSTRACT

THE USE OF ZEOLITE FOR STABILIZATION OF EXTRACT FORMULATION AS ANTIBACTERIAL. A research on the use of zeolite for stabilization of extract formulation as antibacterial has been conducted. Antibacterial extract used is obtained from the extraction of pomegranate peel using ethanol. Antibacterial extract mixed with zeolite for 24 hours at a speed of $150 \mathrm{rpm}$ and a temperature of $27^{\circ} \mathrm{C}$ is subsequently heated at $38^{\circ} \mathrm{C}$ for 24 hours. The results show that the zeolite is able to maintain the stability of the antibacterial activity of the extract formula. In observation of the growth of Bacillus cereus bacteria for 24 hours, a combined extractzeolite formula that has been heated is able to inhibit the growth of bacteria at the second hour to the zero point. When compared with the extract formula without zeolite under the same condition, it is not able to inhibit the growth of bacteria to the zero point of growth curve of bacteria. The number of bacteria increased from 106 to nearly 109 bacterial colonies. This condition shows the combined extract-zeolite is able to maintain the antibacterial activity of the extract formula to heating at a temperature of $38^{\circ} \mathrm{C}$ for 24 hours.

Keywords: Natural zeolite, Pomegranate peel extract, Antibacterial activity

\section{PENDAHULUAN}

Beberapa tanaman obat memiliki potensi sebagai antibakteri. Salah satunya adalah kulit buah delima yang mampu menghambat pertumbuhan Staphylococcus aureus, Bacillus cereus, Bacillus subtilis, Eschericia coli dan Salmonella (Al Zoreky 2009; Chun et al. 2010; Choi et al. 2009; Fei et al. 2011; Fiuza et al. 2009). Kemampuan atau potensi antibakteri sangat mudah dipengaruhi oleh panas, cahaya dan juga $\mathrm{pH}$ dengan cara mendegradasi kemampuan antibakteri sehingga produk antibakteri dan turunannya tidak aman untuk dikonsumsi (Puttarak et al. 2010; Franje et al. 2010). Formulasi antara zat antibakteri dengan zeolit diharapkan mampu memberikan jawaban atas kekurangan tersebut.

Formulasi melalui komposit zat antibakteri dengan suatu polimer telah banyak dikembangkan dalam berbagai bidang (Bala et al. 2011; Konwar et al. 2010). Mekanisme 
penyerapan zat antibakteri pada permukaan polimer dapat digunakan sebagai stabilisator untuk mencegah terjadinya aglomerasi dan presipitasi partikel. Hal ini memberikan arah penggunaan zeolit alam sebagai pengganti polimer yang memiliki banyak keunikan serta aplikasi.

Zeolit merupakan salah satu bahan alam yang banyak dikenal dan digunakan sebagai adsorben dan penyerap limbah. Mineral ini bersifat unik dan khas karena memiliki struktur kristal alumina silikat yang berbentuk rangka tiga dimensi, mempunyai rongga dan saluran serta mengandung ion-ion logam serta molekul air. Keunikan sifat zeolit dimanfaatkan untuk berbagai aplikasi pada industri, pertanian, perikanan dan juga energi. Sifat adsorpsi maupun absorpsi zeolit terhadap bahan organik, anorganik, gas maupun cairan diungkapkan dalam beberapa penelitian mengenai pengolahan limbah, pemurnian dan sensor (Hrenovic dan Tibljas 2002; Li dan Dutta 2010; Srihapsari 2006).

Penelitian mengenai zeolit sebagai pengganti polimer yang digabungkan dengan zat antibakteri belum ditemukan, sehingga kemampuan dan sifat zeolit tersebut menginspirasi penggunaan zeolit sebagai bahan yang mampu membantu suatu sediaan antibakteri dalam menjaga stabilitasnya terhadap pengaruh panas, cahaya, atau $\mathrm{pH}$, sehingga efektivitas kerja antibakteri dapat tetap terjaga. Terobosan dalam mengkombinasi dua material yang memiliki kemampuan seperti tersebut di atas diharapkan dapat melahirkan produk unggulan yang dapat diaplikasikan pada bidang kesehatan dan kecantikan, sehingga meningkatkan nilai ekonomi, potensi ragam penggunaan serta meningkatkan kiprah keilmuan pada bidang bahan alam di dunia internasional.

Zeolit merupakan mineral hasil tambang yang bersifat lunak dan mudah kering. Zeolit yang digunakan berasal dari Cikalong memiliki warna putih kehijau-hijauan. Zeolit terbentuk dari abu vulkanik yang telah mengendap jutaan tahun silam. Sifat-sifat mineral zeolit sangat bervariasi tergantung dari jenis dan kadar mineral zeolit. Menurut Arif (2011), kandungan mineral zeolit Cikalong terdiri dari $\mathrm{Si}, \mathrm{Al}, \mathrm{Ca}, \mathrm{Fe}$, $\mathrm{K}, \mathrm{Mg}$ dan $\mathrm{Na}$ (Tabel 1). Zeolit mempunyai struktur berongga, biasanya rongga ini diisi oleh air serta kation yang bisa dipertukarkan dan memiliki ukuran pori tertentu. Oleh karena itu zeolit dapat dimanfaatkan sebagai penyaring molekuler, senyawa penukar ion, sebagai filter dan katalis.
Kandungan air dalam zeolit berkisar 1\% sampai dengan $35 \%$. Perbandingan antara atom Si dan Al akan menghasilkan banyak variasi zeolit.

Struktur tektosilikat yang diperlihatkan pada Gambar 1 menunjukkan beberapa atom Si digantikan oleh atom Al melalui substitusi isomorfik, menghasilkan struktur bermuatan negatif yang berasal dari perbedaan antara tetrahedral $\left(\mathrm{AlO}_{4}\right)^{5-}$ dan $\left(\mathrm{SiO}_{4}\right)^{4-}$.

Zeolit memiliki sifat kimia sebagai penjerap gas atau cairan (Ginting et al. 2007), adsorben limbah pencemar seperti fosfor, besi, krom dan beberapa logam lainnya (Hrenovic dan Tbiljas 2002; Susetyaningsih et al. 2009), pertukaran ion (Ginting et al. 2007; Arif 2011; Subariyah et al. 2013)

Tabel 1. Analisis unsur zeolit alam Cikalong

\begin{tabular}{cc}
\hline Unsur & Kadar (\%) \\
\hline $\mathrm{Si}$ & 68.4 \\
$\mathrm{Al}$ & 10.3 \\
$\mathrm{Ca}$ & 9.57 \\
$\mathrm{Fe}$ & 6.57 \\
$\mathrm{~K}$ & 4.33 \\
$\mathrm{Mg}$ & 0.570 \\
$\mathrm{Na}$ & 0.285
\end{tabular}

Sumber: Arif (2011)

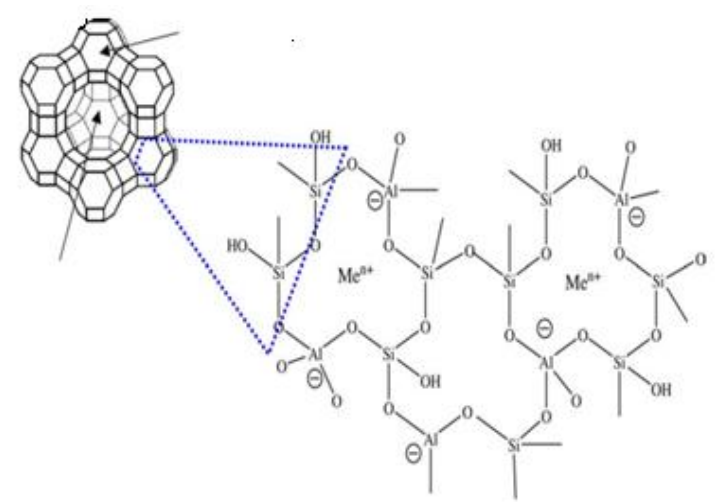

Gambar 1. Kerangka struktur zeolit (Valdes et al. 2006)

Penelitian ini bertujuan untuk mengetahui potensi zeolit alam sebagai bahan yang membantu sediaan antibakteri dalam melindungi dari pengaruh panas sehingga efektivitas kerja antibakteri dapat terjaga. 


\section{BAHAN DAN METODE}

Bahan

Bahan yang digunakan dalam penelitian ini antara lain zeolit yang diperoleh dari daerah Cikalong, digerus dan diayak hingga berukuran 100 mesh. Ekstrak tanaman obat diperoleh dari kulit buah delima, daun dewandaru, kumis kucing dan tabat barito. Sebagai bakteri uji digunakan Bacillus cereus 0,5 Mc Farland. Sedangkan peralatan yang digunakan antara lain shaker, oven, dan pengaduk-pemanas magnet.

\section{Metode}

Pada penelitian ini dilakukan formulasi ekstrak tanaman obat yang sebelumnya diketahui memiliki aktivitas antibakteri dengan zeolit yang dilanjutkan dengan pengujian efektivitas hasil formulasi.

Formulasi dilakukan dengan cara modifikasi metode yang disampaikan oleh Bektas dan Kara (2004) dengan cara mencampurkan formula ekstrak dengan zeolit pada perbandingan 1:1 yang digoyang selama 24 jam pada kecepatan $150 \mathrm{rpm}$ dan suhu $27{ }^{\circ} \mathrm{C}$. Endapan yang dihasilkan dipisahkan dari supernatan, dicuci dengan masing-masing pelarut yaitu air, etanol $30 \%$ dan etanol $96 \%$, kemudian dikeringkan dengan cara dianginkan di udara terbuka. Sebagian sampel yang diperoleh selanjutnya dipanaskan pada suhu $38{ }^{\circ} \mathrm{C}$ selama 24 jam, kemudian seluruhnya diuji efektivitasnya.

Uji efektivitas dilakukan terhadap semua komponen bahan uji untuk mendapatkan kurva pertumbuhan bakteri melalui pengamatan selama 24 jam. Metode yang digunakan adalah metode tuang SNI 2897-2008.

Zeolit, formula ekstrak sebelum dan sesudah pemanasan, formula gabungan ekstrak-zeolit sebelum dan sesudah pemanasan, kontrol positif dan kontrol negatif dimasukkan sejumlah $25 \mathrm{~g}$ ke dalam $225 \mathrm{~mL}$ NB yang telah berisi bakteri uji 0,5 Mc Farland atau pada kisaran absorbansi 0,132 pada panjang gelombang $600 \mathrm{~nm}$. $1 \mathrm{~mL}$ sampel uji diambil tiap 1 jam selama 24 jam pada 2 cawan petri yang ditambahkan $20 \mathrm{ml}$ NA atau Plate Count Agar $(P C A)$. Selanjutnya diinkubasi selama 24 jam pada masing-masing suhu inkubasi. Dihitung jumlah koloni pada masing-masing cawan untuk selanjutnya dibuat kurva pertumbuhan sebagaimana yang dimaksud.

\section{HASIL DAN PEMBAHASAN}

Pengamatan pertama dilakukan dengan melihat secara fisik perubahan yang terjadi pada formula ekstrak dan gabungan ekstrak dengan zeolit sebelum dan sesudah dipanaskan pada suhu $38{ }^{\circ} \mathrm{C}$ selama 24 jam. Terlihat bahwa perubahan yang terjadi melalui pemanasan tersebut menyebabkan pelelehan formula ekstrak sedangkan gabungan ekstrak-zeolit tidak mengalami perubahan. Kondisi tersebut diperlihatkan pada Gambar 2.

Gambar 3 menjelaskan bahwa pada konsentrasi ekstrak $100 \mathrm{mg} / \mathrm{mL}$ diperoleh enam kurva pertumbuhan. Pertama, kurva pertumbuhan bakteri setelah ditambahkan zeolit Cikalong. Kurva menunjukkan pertumbuhan bakteri hampir sama dengan pertumbuhan bakteri normal $B$. cereus, berawal pada jumlah koloni bakteri $10^{6}$, terus meningkat sampai dengan jumlah koloni $10^{11}$ dan mengalami fase stasioner.

Pengamatan dilanjutkan dengan mencari formula ekstrak yang memiliki aktivitas antibakteri yang terbaik. Hasil pengamatan ditunjukkan padaTabel 1.

Hasil uji dua belas ekstrak tanaman menunjukkan bahwa ekstrak kulit delima dengan pelarut etanol $96 \%$ memberikan aktivitas terbaik terhadap bakteri Bacillus cereus. Formula ini segera dilanjutkan pada tahap selanjutnya yaitu mencari efektifitasnya terhadap bakteri tersebut yang ditunjukkan pada Gambar 3.

Gambar 3 menjelaskan bahwa pada konsentrasi ekstrak $100 \mathrm{mg} / \mathrm{mL}$ diperoleh enam kurva pertumbuhan. Kurva pertama (B. cereus) adalah kurva pertumbuhan bakteri normal. Kurva pertumbuhan yang dimulai pada jam ke 0 masa inkubasi dan jumlah koloni bakteri $10^{6}$ yang selanjutnya mulai mengalami fasa stasioner pada jam ke 16 masa inkubasi 24 jam.

Kurva kedua (ZC) adalah bentuk kurva pertumbuhan bakteri setelah ditambahkan zeolit Cikalong dimana bentuknya menunjukkan pertumbuhan bakteri sama dengan kurva pertumbuhan bakteri normal (kurva pertama), berawal pada jam ke 0 dengan jumlah koloni bakteri $10^{6}$. Terus meningkat sampai dengan jumlah koloni $10^{11}$ dan selanjutnya mengalami fase stasioner pada jam ke 16. Kurva ini menunjukkan bahwa tidak ada aktivitas antibakteri pada zeolit karena pertumbuhan bakteri normal sama dengan pertumbuhan bakteri setelah ditambahkan zeolit. 


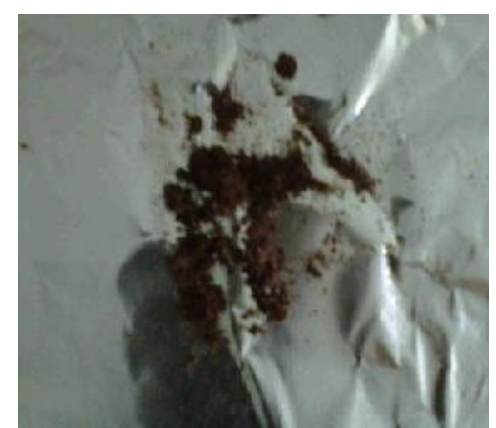

formula ekstrak sebelum

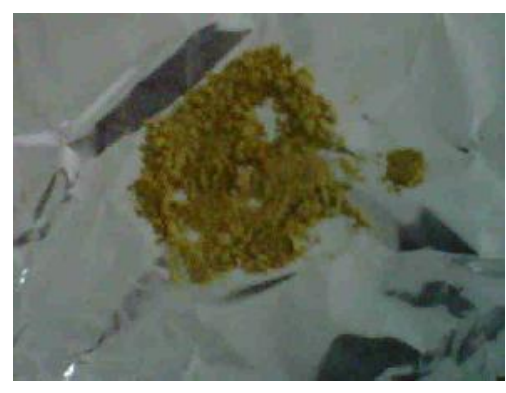

gabungan ekstrak-zeolit sebelum

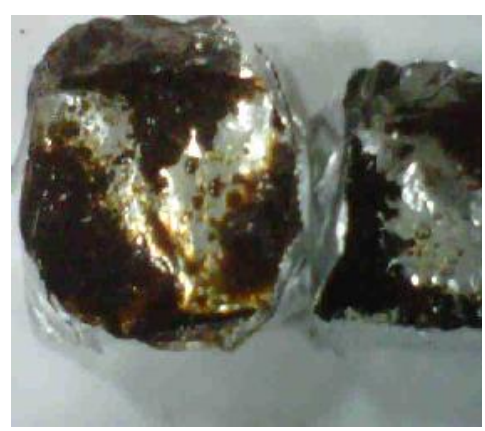

formula ekstrak sesudah

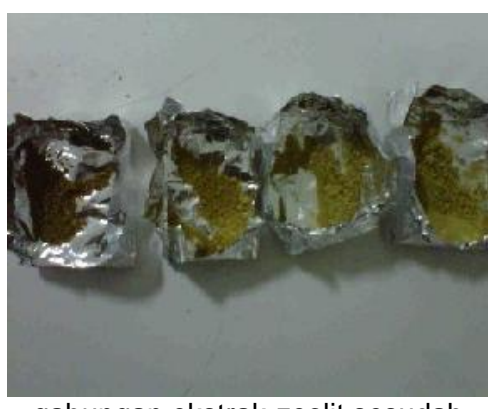

gabungan ekstrak-zeolit sesudah

Gambar 2. Formula ekstrak dan gabungan zeolit-ekstrak sebelum dan setelah dipanaskan pada suhu $38^{\circ} \mathrm{C}$ selama 24 jam.

Tabel 1 Hasil uji aktivitas antibakteri dua belas ekstrak tunggal pada berbagai konsentrasi, kontrol positif klor amfenikol 0,03 mg/mL dan ampisilin 0,01 mg/mL terhadap bakteri Bacillus cereus ATCC 11778

\begin{tabular}{|c|c|c|c|c|c|c|}
\hline \multirow{2}{*}{$\begin{array}{l}\text { Nama } \\
\text { Ekstrak }\end{array}$} & \multicolumn{6}{|c|}{ Diameter Daerah Hambatan (mm) } \\
\hline & $0,01 \mathrm{mg} / \mathrm{mL}$ & $0,03 \mathrm{mg} / \mathrm{mL}$ & $0,75 \mathrm{mg} / \mathrm{mL}$ & $7,5 \mathrm{mg} / \mathrm{mL}$ & $15 \mathrm{mg} / \mathrm{mL}$ & $37,5 \mathrm{mg} / \mathrm{mL}$ \\
\hline EAKD & 0,00 & 0,00 & 0,00 & 17,02 & 19,52 & 22,76 \\
\hline EE3KD & 0,00 & 0,00 & 0,00 & 16,98 & 18,98 & 19,54 \\
\hline EE9KD & 0,00 & 0,00 & 12,66 & 20,48 & 22,02 & 24,28 \\
\hline EADW & 0,00 & 0,00 & 0,00 & 16,37 & 17,16 & 21,70 \\
\hline EE3DW & 0,00 & 0,00 & 0,00 & 16,18 & 17,05 & 21,81 \\
\hline EE9DW & 0,00 & 0,00 & 0,00 & 14,44 & 16,29 & 21,61 \\
\hline EAKK & 0,00 & 0,00 & 0,00 & 12,93 & 12,99 & 18,05 \\
\hline EE3KK & 0,00 & 0,00 & 0,00 & 14,34 & 14,76 & 18,07 \\
\hline EE9KK & 0,00 & 0,00 & 0,00 & 13,04 & 13,12 & 17,83 \\
\hline EATB & 0,00 & 0,00 & 0,00 & 12,39 & 12,97 & 16,68 \\
\hline EE3TB & 0,00 & 0,00 & 0,00 & 17,25 & 18,62 & 23,14 \\
\hline EE9TB & 0,00 & 0,00 & 0,00 & 11,44 & 12,65 & 18,37 \\
\hline Kloramfenikol & - & 23,00 & - & - & - & - \\
\hline Ampisilin & 12,00 & - & - & - & - & - \\
\hline \multicolumn{3}{|c|}{$\begin{array}{l}\text { EAKD }=\text { Ekstrak Air Kulit Delima } \\
\text { EE3KD }=\text { Ekstrak Etanol 30\% Kulit Delima } \\
\text { EE9KD }=\text { Ekstrak Etanol 96\% Kulit Delima } \\
\text { EADW }=\text { Ekstrak Air Dewandaru } \\
\text { EE3DW }=\text { Ekstrak Etanol 30\% Dewandaru } \\
\text { EE9KD }=\text { Ekstrak Etanol 96\% Dewandaru }\end{array}$} & \multicolumn{4}{|c|}{$\begin{array}{l}\text { EAKK }=\text { Ekstrak Air Kumis Kucing } \\
\text { EE3KK }=\text { Ekstrak Etanol 30\% Kumis kucing } \\
\text { EE9KK }=\text { Ekstrak Etanol 96\% Kumis Kucing } \\
\text { EATB }=\text { Ekstrak Air Tabat Barito } \\
\text { EE3TB }=\text { Ekstrak Etanol 30\% Tabat Barito } \\
\text { EE9TB }=\text { Ekstrak Etanol } 96 \% \text { Tabat Barito }\end{array}$} \\
\hline
\end{tabular}




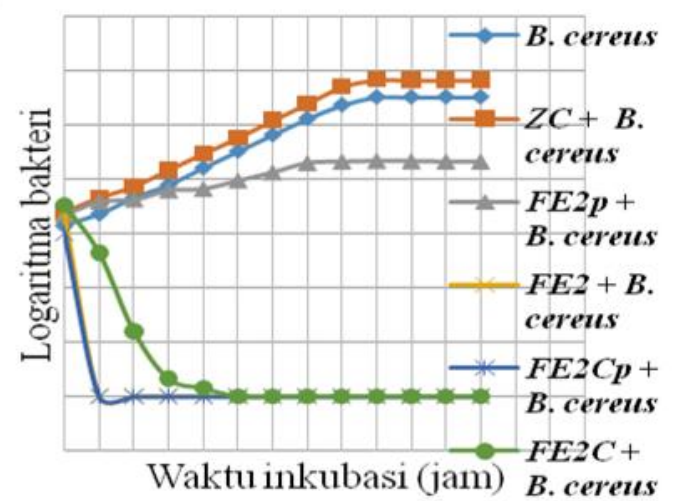

Gambar 3. Kurva pertumbuhan B. cereus dalam nutrient broth setelah ditambahkan formula ekstrak dan gabungan zeolitekstrak yang telah dipanaskan pada suhu $38^{\circ} \mathrm{C}$

$\begin{array}{lll}\text { Keterangan: } & \\ \text { ZC } & & \text { zeolit cikalong } \\ \text { FE2p } & = & \text { formula ekstrak setelah dipanaskan } \\ \text { FE2 } & = & \text { formula ekstrak sebelum dipanaskan } \\ \text { FE2Cp } & = & \text { gabungan ekstrak-zeolit setelah dipanaskan } \\ \text { FE2C } & = & \text { gabungan ekstrak-zeolit sebelum } \\ & \text { dipanaskan }\end{array}$

Kurva ketiga (FE2p) adalah kurva pertumbuhan bakteri formula ekstrak setelah dipanaskan. Kurva ini menunjukkan pertumbuhan bakteri yang terganggu dari pertumbuhan bakteri normal. FE2 $p$ kehilangan aktivitas antibakteri setelah dipanaskan pada suhu $38{ }^{\circ} \mathrm{C}$ selama 24 jam. Kurva pertumbuhan bakteri meningkat dari $10^{6}$ koloni bakteri menjadi lebih dari $10^{8}$ koloni bakteri pada fasa stasioner. Berbeda dengan jumlah koloni bakteri pada kurva keempat (FE2) dimana formula ekstrak sebelum dipanaskan mampu menghambat jumlah koloni bakteri sampai pada angka nol pada jam kedua. Hasil tersebut menunjukkan bahwa, formula ekstrak kehilangan stabilitasnya setelah dipanaskan, seperti yang telah diungkapkan Puttarak et al. (2010) bahwa aktivitas senyawa antimikroba mudah dipengaruhi oleh panas, dan panas yang diberikan mendegradasi struktur senyawa antimikroba (Franje et al. 2010).

Pada kurva kelima (FE2C), formula gabungan ekstrak dengan zeolit sebelum dipanaskan mampu menghambat pertumbuhan bakteri sampai dengan angka nol jumlah bakteri pada jam kesepuluh. Sedangkan dari kurva keenam (FE2Cp) diketahui bahwa gabungan formula ekstrak-zeolit setelah dipanaskan mampu menghambat pertumbuhan bakteri sampai dengan angka nol jumlah bakteri pada jam kedua. Hal ini menunjukkan bahwa pemanasan yang diberikan pada gabungan formula ekstrak zeolit mampu meningkatkan efektivitas formula dalam membunuh bakteri. Kemampuan ini serupa dengan formula ekstrak tanpa zeolit sebelum dipanaskan. Panas yang diberikan pada zeolit memperbesar luas permukaan atau rongga zeolit. Jika luas permukaan material makin besar maka kemungkinan zat yang terjerap dipermukaan makin besar, dan jika rongga material semakin besar maka zat yang terjebak juga akan semakin banyak. Banyaknya zat yang terjebak menyebabkan efektivitas suatu zat semakin besar.

Zeolit ternyata mampu memberikan perlindungan yang baik bagi kemampuan formula ekstrak dalam membunuh bakteri. Hal ini dapat diketahui dari kurva FE2Cp dan FE2p. Formula ekstrak yang telah dipanaskan tidak mampu membunuh bakteri pada jam kedua seperti yang dapat dilakukan oleh formula ekstrak yang telah digabung zeolit setelah dipanaskan. Zeolit sebagai adsorben mampu menjadi stabilizer panas, menahan aglomerasi dan presipitasi partikel zat aktif antibakteri tanaman obat kulit buah delima.

\section{KESIMPULAN}

Zeolit mampu melindungi aktivitas senyawa antibakteri dari panas sehingga sinergi antara zeolit dan formula ekstrak setelah dipanaskan mempertahankan efektivitas sifat antibakteri dan zeolit dapat digunakan sebagai bahan yang dapat menjaga stabilitas antibakteri.

\section{UCAPAN TERIMA KASIH}

Penulis mengucapkan terima kasih yang tak terhingga atas bimbingan dan segala bantuan untuk penelitian ini kepada yang terhormat Ibu Dyah Iswantini Pradono, Ibu Sri Budiarti dan Bapak Zaenal Abidin.

\section{DAFTAR PUSTAKA}

Al-Zoreky, NS. 2009. "Antimicrobial Activity of Pomegranate (Punica-granatum L.) Fruit Peels." International Journal of Food Microbiology 134:244-248.

Arif, Z. 2011. "Karakterisasi dan Modifikasi Zeolit Alam sebagai Bahan Media Pendeteksi Studi Kasus: Kromium Heksavalen." Bogor: Fakultas Matematika dan IImu Pengetahuan, Institut Pertanian Bogor.

Bala, T., G. Armstrong, F. Laffir, dan R. Thornton. 2011. "Titania-silver and alumina-silver composite nanoparticles: 
novel, versatile synthesis, reaction mechanism and potensial antimicrobial application." Elsevier. Colloid and Interface Science 1-26.

Bektaş N, dan S. Kara. 2004. "Removal of lead from aqueous solutions by natural clinoptilolite: equilibrium and kinetic studies." Sep Purif Technol 39(3):189-200. doi: 10.1016/j.seppur.2003.12.001.

Choi, G.J. 2009. "In Vitro and In Vivo Antibacterial Activity of Punicagra-natum Peel Ethanol Extract Against Salmonella." eCAMoxfordjournals. Nep 105:1-8.

Chun, H.H., N. Ismail, F.S. Shaida, dan R. Ahmad. 2010. "In Vitro Antibacterial and Antioxidant Activities of Orthosi-phon Stamineus Benth." Extract Against Foodbone Bacteria. Food Chemistry 122:11681172.

Franje C.A. 2010. "Differential Heat Stability of Amphenicols Characte-rized by Structural Degradation, Mass Spectrometry and Antimicro-bial Activity." Journal of Pharmaceutical and Biomedical Analysis 53:869-877.

Fei, L., L. Qipeng, L. dan Chunfang. 2011. "In Vitro Antimicrobial Effect and Mechanism of Action of Selected Plant Essential Oil Combination Against Four Food-Related Micro-organism." Food Research International 44:3057-3064.

Fiuza T.S. 2009. "Antimicrobial Activity of The Crude Ethanol Extract and Fraction from Eugenia uniflora Leaves Against Pseudomonas aeruginosa." Latin American Journal of Pharmacy 28:892-898.

Ginting A.B., D. Anggraini, S. Indaryati, dan R. Kriswarini. 2007. "Karakterisasi Komposisi Kimia, Luas Permukaan Pori dan Sifat Termal dari Zeolit Bayah, Tasikmalaya, dan Lam-pung." J.Tek.Bhn.Nukl. 3(1):1-48.
Hrenovic, J., dan D. Tibljas. 2002. "Phosphorus Removal from Waste-water by Bioaugmented Activated Sludge with Different Amounts of Natural Zeolit Addition." Elsievier Science 142:1743-1750.

Konwar, U., N. Karak, dan M. Mandal. 2010. "Vegetable oil based highly bran-ched polyester/clay silver nano-composites as antimicrobial surface coating materials." Elsevier Organic Coatings 68:265-273.

Li, X., dan P.K. Dutta. 2010. "Interaction of Dimethylmethylphosphonate with Zeolite Y:Impedance-Based Sensor for Detecting Nerve Agent Simultans." J.Phys.Chem.C. 114: 7986-7994.

Puttatak, P., T. Charoonratana, dan Panichayupakaranant. 2010. "Anti-microbial Activity and Stability of Rhinacanthins-rich Rhinacanthus-nasutus Extract." Phytomedicine Journal Elsevier 17:323-327

Srihapsari, D. 2006. "Penggunaan Zeolit Alam yang telah Diaktivasi dengan Larutan $\mathrm{HCl}$ untuk Menjerap Logam-logam Penyebab Kesadah-an Air." Semarang: Fakultas Matematika dan IImu Pengetahuan Alam, Universitas Negeri Semarang.

Susetyaningsih, R., E. Kismolo, dan Prayitno. 2009. "Karakterisasi zeolit alam pada reduksi kadar krom dalam limbah cair." Seminar Nasional $V$ SDM Nuklir. Yogyakarta.

Valdes, M. G., A.I.P. Cordoves, dan M.E.D.Garcia. 2006. "Zeolites and zeolitbased materials in analytical chemistry." Trends in Analytical Chemistry 25 (1): 24-30.

Subariyah, I., A. Zakaria, dan Y. Purwamargapratala. 2013. "Karakterisasi Zeolit Alam Lampung Teraktivasi Asam Klorida dan Termodifikasi Asam Fosfat." Jurnal Teknologi Pengelolaan Limbah 16 (3) ISSN1410-9565:17-24. 